Giuseppe Mari*

ORCID: 0000-0001-5437-7899

Milan, Italy

\title{
Christian Faith as an Important Element of Culture and Integral Education
}

\section{Wiara chrześcijańska jako istotny element kultury i integralnego wychowania}

Summary: The article, referring to the words of the Letter to Diognetus on Christians as the soul of the world, points to the importance of the Christian faith and its believers - Christians in Europe and in the world, especially in the field of culture and education, which are characterized by an integral approach. This problem is analysed in successive three stages: 1) first, integrity is indicated as an essential feature of the Christian faith and education that has been clearly marked from the very beginnings of Christianity; 2) shows faith as the basic expression of human identity, also consistent with the freedom that gives its identity; 3) critically analyses the secularity, indicating in this context the need to promote the integrity of the upbringing of the person and the cultural and social benefits that the Christian faith can bring. Especially during the present loss of the ability to distinguish between important and less important things, when apart from the need to rethink the idea of secularity, the possibility of a positive culmination is pointed out. Christian faith can be an impor-

* Prof. Giuseppe Mari PhD is the full professor of the General Pedagogy in Catholic University of Sacred Heart of Milan. Address Università Cattolica del Sacro Cuore, Facoltà di Scienze della Formazione, Largo A. Gemelli, 1 - 20123 Milano; e-mail: giuseppe.mari@, unicatt.it. 
tant element of integral culture and integral education in action for humanization. In this action, reason and faith, as "two wings" can lead to true wisdom.

Keywords: faith; reason; Christianity; integrity; culture; integral education; secularity; secularism; essence and significance of faith.

Streszczenie: Artykuł nawiązując do słów Listu do Diogneta o chrześcijanach jako duszy świata, wskazuje na znaczenie wiary chrześcijańskiej i jej wyznawców chrześcijan dla Europy i dla świata zwłaszcza w obszarze kultury i wychowania, które charakteryzują się podejściem integralnym. Tę problematykę analizuje się w następujących po sobie trzech etapach: 1) najpierw wskazuje się na integralność jako istotną cechę wiary i wychowania chrześcijańskiego zaznaczającą się wyraźnie już od samych początków chrześcijaństwa; 2) ukazuje wiarę jako podstawowy wyraz ludzkiej tożsamości, zgodny także z wolnością, która nadaje jej tożsamości; 3) poddaje krytycznej analizie laickość, wskazując w tym kontekście na potrzebę promowania integralności wychowania osoby oraz na kulturowe i społeczne korzyści, jakie zdolna jest wnosić wiara chrześcijańska. Zwłaszcza w obecnej utracie zdolności rozróżniania rzeczy ważnych i mniej ważnych, gdy obok potrzeby przemyślenia idei laickości wskazuje się na możliwości pozytywnego jej zwieńczenia, wiara chrześcijańska może stanowić istotny element integralnej kultury i integralnego wychowania w działaniu na rzecz humanizacji. W tym działaniu rozum i wiara, jako „dwa skrzydła”, mogą prowadzić do prawdziwej mądrości.

Słowa kluczowe: wiara; rozum; chrześcijaństwo; integralność; kultura; integralne wychowanie; laickość; sekularyzm; istota i istotność wiary.

The text from the second century - The Letter to Diognetus ${ }^{1}-$ compares $^{2}$ Christians living in the world to the soul in its relation to the body ${ }^{2}$. Pope Francis referred to this ancient Christian testimony when, on October 28, 2007, he addressed the conference participants on the subject of: (Re)thinking Europe, organized by the Conference of the Bishops of Europe in cooperation with the Secretary of State of the Holy See. That was the message of the Pope:

1 “The Letter to Diognetus", http://www.vatican.va/spirit/documents/spirit_20010522_diogneto_en.html [access: 18.10.2018].

${ }^{2}$ Ibidem, $\mathrm{n}^{\mathrm{o}} 6$. 
The author of The Letter to Diognetus states that 'just as the soul in the flesh, so are the Christians in the world'. At the present time, they are called to restore the soul of Europe, to restore awareness and the awakening of the conscience, not to occupy certain positions - it would be proselytizing - but to animate processes that will generate new dynamics in society. This is exactly what Saint Benedict did and it was no coincidence that he was declared Patron of Europe by Paul VI; he did not seek to take a position in a lost world that had strayed. Strengthened by faith, he continued to search and from a small cave in Subiaco, this search gave rise to a thrilling and irreversible movement that remodelled the face of Europe.

In the words of Pope Bergoglio the exhortations of his predecessors addressed to Europe lost in the realm of order related to the recognition of its "Christian roots" resound ${ }^{3}$. In fact, the reference to the necessity of faith (and thus education) of Christians is not only about Europe, but about the entire world, which is vulnerable to drifting, which seems to overlook what is essential for human life and what, in fact, all Popes often spoke of, especially when they had the opportunity to speak at the United Nations forum (ONU) ${ }^{4}$.

But what is the most important for the liberation of these potentialities inherent in human life?

This question is answered by the integrity of the educational practice. It is based on a logic that is not appreciated, particularly today. When we have access to a variety of messages humanity risks of not being able to distinguish what is most important from what is of lesser importance. This task requires the adoption of a certain orientation principle, because otherwise an avalanche of news could drown us in the stream of information we have access to. What gives such an orientation results from the essence itself, its existence - as a requirement. Therefore, one should follow this vision which can go beyond the established level, to be able to recognize what is basic and thus to continue to do so. The point is to avoid contentment with descriptive and contextual knowledge and to go beyond temporary and transient predictability.

3 Cfr. John Paul II, "Ecclesia in Europa”, http://w2.vatican.va/content/john-paul-ii/ en/apost_exhortations/documents/hf_jp-ii_exh_20030628_ecclesia-in-europa.html [access: 18.10.2018]; on the theme of Pope Benedict XVI, cfr. Joseph Ratzinger, Europa (Milano: San Paolo, 2004).

${ }^{4}$ Paul VI paid a visit to the ONU on 4.10.1965; John Paul II on October 2, 1979 and November 1, 1995 (2.6.1980 he spoke in UNESCO); Benedict XVI on 18.4.2008; Pope Francis on 25.9.2015. 
In my article, I would like to contribute to this challenge in the following three stages:

1) identifying integrity as a special challenge essential to Christian faith and education from the very beginning;

2) referring to faith as the basic expression of human identity, consistent with the freedom that identifies it;

3) the recognition, in the critical revision of secularity, of the possibility of promoting the integral upbringing of a person which include the cultural benefits brought by the Christian faith.

\section{In what sense is "integrity" recognizable in faith and Christian education from the very beginning?}

Christianity was founded in a remote province of the Roman Empire, on the margins of cultural influences and trade routes. And yet, over several decades, it reached Rome, where - in the first half of the second century - the philosopher Justin, having converted to the new faith, opened a school. Soon after something similar happened in Alexandria, Egypt - after the capital, the most important city of the Empire - where the Didaskaleion was transformed into a catechetical school, but with cultural openness. As a result it could compete with the great philosophical schools of that time, as shown by the development of theologians such as Clement and Origen.

These brief references to history allow us to understand that Christianity - from the moment it was created - aroused the interest not only of those who lived on the margins of ancient society, but also intellectuals and people of culture.

We know the deep crisis the world was passing through during those times which is well reflected in words taken from the Gnostic text from the second century: "he escapes without knowing where or what is expected, without knowing whom"s. We understand, therefore, the importance of the rebuke received in the oldest Gospel: "What good is it for a man, if he gains the whole world, and suffers his own loss?" (Mk 8:36). In Paul's letters we also find a telling passage expressed in the form of an imaginary dialogue between the Apostle with the interlocutor asking: "All things are lawful for

${ }^{5}$ Included in Eric R. Dodds, Pagani e cristiani in un'epoca di angoscia (Firenze: La Nuova Italia, 1988), 15. 
me, but not all things are helpful. All things are lawful for me, but I will not be dominated by anything" (1 Corinthians $6: 12$ ). In both cases - in fact the second about fifteen / twenty years from the time of Christ's teaching a challenge emerges not to lose what is important, i.e. not to lose what is most important for human existence.

We are aware of the prophetic potential of the Christian message. We know how this prophetic potential was one of the main paths in the Old Testament, where true prophets are those who refer to God's plan and suffer persecution or experience diverse forms of exclusion of false prophets, including those possessing power, and the supporters of "trends", as we call them today. Their integrity corresponds to the veracity of their words and gestures, which do not aim to let their conscience slumber but rather to put to it the responsibility of answering what they are.

It is important to remember, that the entire history of salvation, from its origins as to that completely presented by the New Testament message "good news" (euagghélion in Greek) is about calling for transformation. It is, moreover, what the Greek word metánoia expresses, the "conversion" which distinguishes the change of nous, or what the Latin people called the mens: the way in which life is perceived and the mode of action appropriate to it. It corresponds to this three-complementary anthropology (body-soulspirit), which especially in Paul's writings, in addition to this traditional anthropology of Greek origin, is played by the soul-body pair.

The "Spirit" actually refers to the gift of God, being "received" (Rom $8: 15$; 1 Cor 2:12). Reborn "from the water and the spirit" (Jn 3), the "old man" converts to the "new" man (Rom 6: 6; Ephesians 4: 22-24; Col 2: 9-10), according to a certain dynamic logic and transformation, which does not escape the attention of the Fathers of the Church. I will limit myself to recalling one of the most ancient testimonies dating back to the time of Irenaeus of Lyon, which clearly refers to Saint Paul and describes the work of the Holy Spirit on the believer, affirming: "when this Spirit merges with the soul and the creation, thanks to the sending of the Holy Spirit, man becomes spiritual and perfect, and this means that he becomes who is created in the Image and Likeness of God"6.

By stating this, the necessity of faith in the recognition of who a human being is, is clearly manifested. We know how marginal it is to refer to it, within the framework of Greek culture, as it is presented well in the cogni-

${ }^{6}$ Ireneo di Lione, Contro le eresie, V, 6, 1 (Siena: Cantagalli, 1968), vol. II, 166. 
tive model of the Platonic Republic, where faith (pistis), including sensory cognition, is at its lowest level ${ }^{7}$.

Consequently, it is not surprising that one of the first aspirations of the Fathers of the Church - in opposition to the pagan world - was to show the importance of faith. An example in this regard is Arnobius the rhetoric, when he writes:

There is an action in life or a matter of special meaning that is not promoted, but is either taken up or initiated with effect for progress in faith? You travel, you sail: do you not believe that you will return home after solving your problem in the process? He will cultivate the soil with the plough and sow it completely with different grains: do you not believe that you will harvest as the season approaches?

You bind yourself through marriage contracts: do you not believe that they will remain pure and that they are the legal relationship of the spouses? You accept the offspring of your children: do you not expect them to stay healthy and reach old age throughout the next stages of life?

But what does this mean for us today in connection with "integral" education?

\section{The significance of faith for human life}

The world in which we live today is no more sensitive - when it comes to the meaning of faith - than the ancient one. For about five centuries, i.e., when modernity begun, faith became tangentially discredited as something that is not quite useless, so if not useless, certainly harmful. Such a stereotype feeds, in particular, on the belief that to believe means to be fanatical, and therefore blind in relation to scientific and technical achievements, closed to dialogical confrontation, intolerant, violent and fundamentalist. It has been forgotten, however, that the 20th century was the most atheistic and agnostic age in history which also became the bloodiest: remembering two World Wars and many occurrences of genocide that were the cause of over one hundred million deaths. Therefore, we cannot say that faith makes people fanatical; it is fanaticism that is the problem of the human existence. This refers

${ }^{7}$ Cfr. Platon, La Repubblica, VI, 509d-511e (Roma: Laterza, 1997).

${ }^{8}$ Arnobio il Retore, Contro i pagani, II, 8 (Roma: Città Nuova, 2017), 175-177. 
to the human heart, a form of "precipice" (Psalm 63: 7), and it is explained by the fact that "from the inside" comes out who the man is (Mk 7:15).

Once we have found that faith does not necessarily give rise to fanaticism let us also confront the stereotype of it being irrelevant. In other words, we have observed that humanity, which sends probes into space and reveals the complexities of the genome, extending knowledge both in terms of what is infinitely large, as well as what is infinitesimally small, then why would it still foster faith? Between the end of the nineteenth and the beginning of the twentieth century, the positivists and idealists differ one from the other (for the positivist's true knowledge could only be scientific, for others, philosophical), nevertheless they were unanimous in stating that faith and knowledge had nothing in common.

Positivist's evaluated faith as pure and simple superstition intended to be removed by scientific enquiry. For idealists, however, it was mythology, in need of purification and to be overcome by philosophy. Is this superstition still present? No, as falsifiable epistemology surrendered the positivist claims of knowledge as always important, the crisis of ideology unmasked the presumption of thought systems that considered themselves final.

Today, what Man discovers is not considered to be definitive and therefore there is an opening for learning associated with faith. Pope Benedict XVI said to do so every time he called for the need to "broaden the idea of rationality".

On the other hand, when the Fathers of the Church had to face the threat of gnosis, which combined salvation with cognition and not with the gift of faith, they did not choose shortcuts by denying the relationship between faith and cognition, but distinguished between "bad" gnosis and "good" gnosis, considering the latter as resulting from the gift of faith. It is worth noting that Klemens of Alexandria pointed out that true knowledge is achieved through the gift of faith and is necessary for the one who has perception, as breathe is for the one who lives ${ }^{10}$.

At the same time, Irenaeus of Lyon attains similar considerations when he distinguishes between "false" and "true" gnosis or the conceit of those

${ }^{9}$ Cfr. Benedetto XVI, "Discorso all'Università di Regensburg”, http://w2.vatican.va/content/benedict-xvi/it/speeches/2006/september/documents/hf_ben-xvi_spe_20060912_university-regensburg.html [access: 18.10.2018]; Benedetto XVI, “Caritas in veritate", no 31, https:// w2.vatican.va/content/benedict-xvi/it/encyclicals/documents/hf_ben-xvi_enc_20090629_caritas-in-veritate.html [access: 18.10.2018].

${ }^{10}$ Cfr. Clemente di Alessandria, Gli Stromati. Note di vera filosofia, II, 6 (Milano, Edizioni Paoline, 2006). 
who use revealed knowledge and the humility of those who have shown faith in listening to God's Word as proclaimed by the Church ${ }^{11}$.

Heretical gnosis maintains that it is possible to achieve definitive cognition by anticipating the "enlightenment" contained in the expression, which reflects the idea of full enlightenment (on the other hand we have a historical period that gave birth to ideology: the value of the word itself dates back to the period of the late enlightenment and Destutt de Tracy). It should be noted that this picture is in direct contradiction to the belief created in antiquity that human cognition can be metaphorically associated with an owl, which moves freely at dusk but cannot fly on a bright day ${ }^{12}$.

This corresponds with the statement of Saint Thomas Aquinas who identifies cognition inherent as "evening", i.e. "imperfect", because "it concerns things as far as they exist in their own nature" and not "in the Word" 13 . Faith, though it isolates enlightenment, does not obscure knowledge, because it refers to the mystery of God Who eludes the human quest. In this sense, the knowledge of faith corresponds to the epistemology of falsification, according to which scientific cognition confirmed by experiments is not eternal, but has meaning until something else is proven: that which is professed by ideologies.

The essence of faith, as close as this, corresponds to what identifies freedom as a special feature of the human condition. In fact, freedom is only in the face of what is not itself self-evident (and compels us to agree). If on a sunny summer's day the question is asked whether the sun is or not, the answer could be unequivocally validated and therefore deprived of liberty. But freedom is distinguished by human existence, and therefore what befits Man is knowledge, not yet definitive, of faith, well-separated from the metaphor of Paul: "now we see in the mirror, poorly, but then we see face to face. I will get to know each of the others perfectly, just as I was known" (1 Corinthians 13:12).

Be that as it may, faith is not only relevant but also adequate to what separates human existence as a rational creation or freedom. It means that one should undermine and reject contemporary objections as to the meaningless

${ }^{11}$ Cfr. Ireneo di Lione, Contro le eresie, IV, 33-41.

${ }_{12}$ Cfr. Aristotele, Metafisica, II, 993b (Milano: Bur, 2009) [This is the answer to Plato's words, La Repubblica, VII, 516a].

${ }^{13}$ Cfr. Tommaso d'Aquino, Somma teologica, I-II, q. 67, a. 3, resp. (Napoli: Libreria Scientifica Editrice, 1965). 
and mischievousness of faith, in favour of reviving the presence of the latter in relation to the culture and integral upbringing of the person.

\section{To reconsider secularism to prevent the absence of the contribution of the Christian view to integral upbringing and culture}

Up to this point, I have tried to recall the importance of the integrity of the Christian perspective in relation to the essence of faith (in the first part of the article), which can also be justified by reference to contemporary stereotypes in order to reject them (in the second part of the article).

Now I will consider further aspects which will lead to the end of this text, questioning the most characteristic features of modern civilization, which should be revised to meet the fruition of the Christian faith in culture and the integral upbringing of the human being. I believe that this is about overcoming the modern concept of secularism.

The stereotypes I have invoked - on the subject of the lack of meaning and harmfulness of faith - have been developed in contemporary times by secularism perceived as a peculiar mission of eliminating faith from the sphere of public life. Such a practice has been confirmed (and it is present in particular in the French environment so far) based on the belief that certain and definitive cognition can be achieved, therefore assuming the possibility of reaching an extraordinary form of human knowledge.

In this perspective the words of Constantin-François Volney, dating back to 1791 , can be used as an example:

The unanimity of opinions assumes assurance in advance, and this means that intellectual gains correspond perfectly to the models to which we relate [...] subjected to sensual perception. [...] From this we deduce that in order to live in peace we must agree not to say anything about objects [which are not noticeable through our senses], so as not to assign them any meaning; in a word, a demarcation line should be drawn between verifiable objects and non-verifiable objects, and a certain inviolable barrier between the world of existence and creations of our fantasy from the real world should be distinguished: meaning excluding all theological and religious attitudes from civil life ${ }^{14}$.

${ }^{14}$ Constantin-François Volney, Solution du problème des contradictions, in: La laicité en mémoire, eds. Guy Gauthier, Claude Nicolet (Paris: Edilig, 1987), 61. 
In this perspective, integrity is seriously compromised, because the scope of cognition is illegally occupied by a concept that considers remarkable only what we discover through our senses. This corresponds to the modern epistemology of verification, which was overcome at the advent of the twentieth century. This explains, also in the French language environment, why a debate about secularity has been undertaken which has evolved into a requirement for re-review, as Sarkozy said in his welcome address to Pope Benedict XVI (12.9.2008) during the pope's visit to Paris. The French president developed the idea of "positive secularity", which opens the perspective of rethinking in the sense both of the universal and public discourse of identity, sustained by faith. Pope Francis recalled this during the visit of the President of the Italian Republic (10.6.2017), referring to "a particular form of secularism, without a hostile confrontation, but friendly and cooperative, despite the clear demarcation, with competences appropriate in public institutions, on the one hand, and religious on the other".

This was followed by the Grande Chambre of the European Court of Human Rights in Strasbourg (18.3.2011) judgment which rejected a motion to remove the Cross from the public space in Italy, justifying this as the presence of a sign containing the symbol of culture and not just an object of a religious cult. Analogical sensitivity can also be found in the German language. Here I refer to the discussion between Cardinal Ratzinger and philosopher Habermas, who, considering the moral foundations of liberal democracy, considered that they originated from Christian enculturation ${ }^{15}$. The "positive" culmination of the idea of secularity opens firm possibilities of reviving the role of faith as an integral vector of cultural and integral education, in which Christianity has an important factor of humanization.

Undertaking this challenge brings a need for awareness of identity, including cognitive faith, expressed recently in the publication of the Apostolic Constitution Veritatis gaudium (8.12.2017). This means, today and always, an invitation to "give Christianity hope" (1 Pt 3:15) which responds to the pursuit of wisdom (sapientia) typical of human cognition, which rises upward in cognition through the "two wings" of reason and faith ${ }^{16}$.

15 Cfr. Jürgen Habermas, "I fondamenti morali prepolitici dello Stato liberale”, in: Jürgen Habermas, Joseph Ratzinger, Etica, religione e Stato liberale (Brescia: Queriniana, 2005), 34-40.

${ }^{16}$ Cfr. John Paul II, "Fides et ratio", the prolog, https://w2.vatican.va/content/john-paul-ii/ en/encyclicals/documents/hf_jp-ii_enc_14091998_fides-et-ratio.html [access: 18.10.2018]. 
The entire vision is that in the absence of one of the two wings flight inevitably weakens and is disturbed. But Man belongs to the species homo sapiens: therefore, the desire to learn has a fundamental meaning for him. This is why we should never give up proclaiming and proposing cultural and integral education flowing from the Christian faith.

\section{References}

Aristotele. Metafisica. Milano: Bur, 2009.

Arnobio il Retore. Contro i pagani. Roma: Città Nuova, 2017.

Benedetto XVI. "Caritas in veritate". https://w2.vatican.va/content/benedict-xvi/it/ encyclicals/documents/hf_ben-xvi_enc_20090629_caritas-in-veritate.html [access: 18.10 .2018$]$

Benedetto XVI. "Discorso all'Università di Regensburg". http://w2.vatican.va/content/benedict-xvi/it/speeches/2006/september/documents/hf_ben-xvi_spe_2006 0912_university-regensburg.html [access: 18.10.2018].

Clemente di Alessandria. Gli Stromati. Note di vera filosofia. Milano, Edizioni Paoline, 2006.

Dodds, Eric R. Pagani e cristiani in un 'epoca di angoscia. Firenze: La Nuova Italia, 1988.

John Paul II. Ecclesia in Europa. http://w2.vatican.va/content/john-paul-ii/en/apost exhortations/documents/hf_jp-ii_exh_20030628_ecclesia-in-europa.html [access: 18.10.2018].

John Paul II. "Fides et ratio". https://w2.vatican.va/content/john-paul-ii/en/encyclicals/documents/hf_jp-ii_enc_14091998_fides-et-ratio.html [access: 18.10.2018].

Habermas, Jürgen. "I fondamenti morali prepolitici dello Stato liberale". In: Joseph Ratzinger, Jürgen Habermas, Etica, religione e Stato liberale. Brescia: Queriniana, 2005.

Ireneo di Lione. Contro le eresie. Siena: Cantagalli, 1968.

Platon. La Repubblica. Roma: Laterza, 1997.

Ratzinger, Joseph. Europa. Milano: San Paolo, 2004.

“The Letter to Diognetus". http://www.vatican.va/spirit/documents/spirit_20010522 _diogneto_en.html [access: 18.10.2018].

Tommaso d'Aquino. Somma teologica. Napoli: Libreria Scientifica Editrice, 1965.

Volney, Constantin-François. "Solution du problème des contradictions". In: La laicité en mémoire, eds. Guy Gauthier, Claude Nicolet. Paris: Edilig, 1987. 
